\title{
FIVE POSSIBLE IMPACTS OF DIGITALISATION IN ROMANIA
}

GRAȚIELA NOJA ${ }^{1}$, CIPRIAN PÂNZARU ${ }^{2,3}$

${ }^{1}$ Department of Marketing and International Economic Relations, West University of Timisoara, Romania

${ }^{2}$ Department of Sociology, West University of Timisoara, Romania

${ }^{3}$ Research Group in Social and Economic Complexity

(C) 2021 Grațiela Noja, Ciprian Pânzaru

This is an open access article distributed under the Creative Commons Attribution-NonCommercial-NoDerivs license (http://creativecommons.org/licenses/by-nc-nd/3.0/)

DOI: $10.1515 /$ eras-2021-0001

\begin{abstract}
The rapid swift towards digital transformations in a globalized modern economy is transforming the skills needed by Europe's workers to maintain their jobs and remain actively integrated on the labour market. As the environment diversifies through the emergence of modern technologies, the working population advances the education for upskilling in a digital era. In this context, understanding the impact of digitalization and finding the appropriate responses is critical. Our paper explores several effects of digitalisation, connected to the Romanian socio-economic specificities.
\end{abstract}

\section{Keywords}

digitalisation, digital skills, future of work, automation, robotization

\section{Introduction}

Digital skills and competences of European Union (EU) citizens (labour force) significantly determine and enhance employment opportunities and economic performance, particularly in a globalized digital economy, where digital technologies shape/transform the labour market and societies at large.

Romania is being placed on the 26th position out of 28 European Union member states within the Digital Economy and Society Index (DESI) for 2020 (European Commission, DESI 2020). Romania's performance was identical in four out of five dimensions measured by DESI, broadband connectivity being the only coordinate where Romania has very good achievements. Romania's digitalization progress has fallen way behind since almost one fifth of the Romanian people have never used the Internet, while a very small share (the lowest in the EU) have used the internet for interaction with public authorities (6\%of people aged 16$74,2017)$, same low performances being accounted in terms of using the internet to order goods or services for private use (18\%of people aged 16-74, 2017).

Moreover, the share of people who never used a computer (percent of people aged 16$74,2017)$ is the highest in EU.

Only $22 \%$ of companies use business software for sharing electronic information (compared to $34 \%$ EU average), $8 \%$ use social media, the similar per cent of companies issue electronic invoice, 5\% use cloud computing (18\%, EU average) and only $7 \%$ sell online (representing a turnover of only $4.3 \%$ ). 
On the other hand, however, Romania holds a strong position as regards the ICT graduates, ranking fifth among the other EU countries (5.6\% compared to the EU average of $3.6 \%$ of total graduates), yet if we consider the employed IT specialists the results are modest, namely $2.2 \%$ compared to an EU average of $3.9 \%$. Higher education institutions (HEI) are a landmark in providing digital skills, being essential in bridging the educational offer with the labor market needs, tailored to professional profiles. The employment rate of recent graduates as a percentage of population aged 20-34 is relatively high in Romania, even though there are notable differences across regions.

At the same time, Romania registered notable achievements in terms of the educational background and labor market insertion of young people, still significantly behind the other EU, again with different performances from one region to another, as attested by the share of people neither in employment nor in education and training. However, the level of digital skills in the country is very low, Romania holding the second to last position among the EU, with no progress compared to the previous year. Same low achievements are registered in terms of 'at least basic' digital skills in the software area. Less than one third of the persons aged 16 to 74 have at least basic digital skills (compared to 58\% overall the EU), while $35 \%$ have at least basic software skills (compared to an EU average of 68\%). The situation is worst if we compare the 'above basic' digital skills, Romania registering only $10 \%$, thus ranking last in the EU in 2020 and without any progress in the last two years.

This paper explored the phenomenon of digitalization in Romania identifying five possible areas of impact. The information that forms the basis of this paper is the result of an extensive desk research based on secondary data analysis using datasets, studies and reports from governmental and private providers.

The paper was elaborated in the context of the ESCALATE* project and some sections were published as reports within this project.

\section{Digital divide}

Digital divide refers to the gap between those who benefit from digital technology and those who do not. As the access to the internet is neither universally available, nor free, poverty tends to stand out as one of the main causes which impair access to an internet connection.

In 2018, 72.4\% of the Romanian households had fixed internet connections. Almost half, $47 \%$ had high-speed connections that allowed download speeds of over $100 \mathrm{Mbps}$. However, there are important differences between urban and rural areas. For instance, according to the National Authority for Management and Regulation in Communications, $75 \%$ of the households with fixed internet connections are in urban areas while, in rural areas, were only $49 \%$. There are also geographic differences. In Bucharest region, 8 out of 9 households had internet connection. The capital region is followed by West and North-West regions, but the lowest levels are in the North-East region (65.1\%) and in the South-East region $(65.2 \%)$. These latter two regions also account for the lowest level of GDP per capita.

The Covid-19 pandemics emphasizes the digital divide. As many students were forced to take online lessons, the access to internet, having a PC, smartphone etc. limited equal access to education. A study employed (AgoraDigi, 2020) during the first stage of the pandemic revealed a huge impact particularly on children from families with social and economic problems.

\footnotetext{
* ESCALATE - Coordinated Higher Institutions Responses to Digitalisation is an EU project co-funded by the
} Erasmus+ programme of the European Union (2019-1-RO01-KA203-063214) 
Age is another variable which contributes to digital divide. Younger generations differ from older generations by technology. The Romanian population is strongly affected by the demographic ageing. Crude rate of total population change, per 1000 persons was -5.0 in 2019 , with a crude birth rate of 9.6 and a crude death rate of 13.4. The median age was 42.5 years. The age structure reflects the existence of demographic ageing phenomenon as a result of the decreasing in the share of young population (0-14 years) and the absolute and relative increase in the share of older people (60 years and over). Proportion of population aged 0-14 years was 15.7 per cent in 2019, while the proportion of population aged 65 years and more was 18.5 per cent, resulting an age dependency ratio (population aged 0-14 and 65 and more to population aged 15-64) of 52.05\%. From the population with the age between 16 and 74, over two third of internet users $(77.7 \%$ ) have the age between 16 and 55 and only $22.3 \%$ have the age over 55.

Moreover, $81.8 \%$ of the users (82.4\% in rural areas and $81.2 \%$ in urban areas) use the internet for participating in social networks (creating user profile posting messages or other contributions to Facebook, Twitter etc.); 63,3\% (63.7\% in rural areas and 69\% in urban areas) use internet for making calls (including video calls), for example via Skype, Messenger, WhatsApp, Facetime, Viber etc., and $57.1 \%$ for sending emails $(50.2 \%$ in rural areas and $64.1 \%$ in urban areas). On the other hand, only $10.3 \%$ (5.3\% in rural areas and $15.4 \%$ in urban areas) use internet banking, 6.4\% (6.1\% in rural areas and 6.8\% in urban areas) for looking for a job or sending a job application over the internet, and only $3.2 \%(2.4 \%$ in rural areas and $4.1 \%$ in urban areas) for selling of goods or services. As it can be noticed, in some cases differences between rural and urban areas are much higher.

Education is another variable which impair the access and use of the internet. The more educated a person is, the bigger opportunity they must have an internet connection. For instance, $96.5 \%$ of households have internet connection if the head of household has a university level of education, $91.5 \%$ in case of upper-secondary education and only $55.5 \%$ for lower-secondary studies or $33.6 \%$ for primary studies.

In conclusion, the case of Romania is very relevant from the point of view of the existence of digital divide. The no access to the Internet increases not only the digital divide, but also a social divide.

\section{Digital skills gaps}

In Romania, the ability of using ICT is considered a key competence that should be provided by school and its importance is highlighted including by the Romanian National Education Law. A discipline in the field of ICT is compulsory starting with the lower secondary level (ISCED 2). Digital competences are further provided through the national curriculum at the upper secondary level (ISCED 3, grade 9-12). Actually, Romania has the highest amount of instruction time allocated for ICT as a compulsory separate subject in compulsory upper secondary education (168 hours) (European Commission/EACEA/Eurydice, 2019). At the ISCED 7-8 level, the digital competencies provided by universities are much more advanced.

Despite this, digital skills gap is widening and fast, with more and more recruiters claiming, for instance, that is difficult to find appropriate candidates. Even though the national curricula oblige educational providers to train digital skills, it seems that here is an important gap between what is provided by school and what is required by the labor market. The experts interviewed reported difficulties in finding appropriate employees from the point of view of required digital skills. Additionally, the PwC Romania's Workforce Disruption Index claimed that about 275,000 Romanian employees should learn in the next decade new or superior digital skills (upskilling) to maintain or find jobs. Another research - PwC Central and Eastern 
Europe Private Business Survey 2019 (PwC Report, 2019) - found that about 18\% of companies mention difficulties in hiring digital experts.

Covid-19 pandemic has accelerated digitalization and will force more and more employees to improve their digital skills. As this is not a simple process, it is expected, at least on a short time, the digital skills gap will be widening.

\section{Future of work}

Global job losses due to digitalization are estimated to 2 billion by 2030 (World Economic Forum, 2018), while the current covid-19 pandemic has outburst on the global economy making digitalization even more relevant and a key milestone to overcome these challenges. As Coibion et al. (2020) underline, the preliminary indicators to assess the impact of Covid-19 on the global economy show dramatic declines in employment (20 million decrease in the number of workers), and a wave of early retirements with obvious negative effects on the economy.

Another particularly worrying aspect that the authors highlight is the fact that most of those who lost their jobs due to the Covid-19 outbreak are not looking for a new job. Also in Romania, because of inherent government public health strategies and social distancing measures to mitigate the spread of Covid-19, many businesses have dwindled the number of workers or even closed all the activities, while other have reoriented their activities online, making digitalization even more relevant and decisively important for any economy.

These challenges are amplified for Romania in the digitalization framework, due to some of the lowest digitalization performances accounted by the country over the years.

Within the EU, the European Commission's Digital Economy Society Index for 2020 (European Commission, DESI 2020) shows that even though several EU countries have registered a notable progress (Ireland, Netherlands, Malta, and Spain), the majority of the countries, which are below the EU average in the level of digitization, have not progressed significantly in the last five years. Hence, the EU Member States still face deep digital development gap, Romania being placed at the bottom of this ranking, along with Greece and Bulgaria. Mas and Pallais (2020) emphasized that "median worker reports that only $6 \%$ of their job could be feasibly done from home", compared with white collar workers from the IT sector or business and financial sector, who can easily work from home. Mongey and Weinberg (2020) prove that individuals who cannot work from home are more likely to be medium or low educated, non-white, lower-income and without employer-provided health insurance. The number of jobs that can be made from home, using digital instruments, will be an important indicator for the economy's performance (Dingel \& Neiman, 2020).

Countries, which will be able to enhance and efficiently use the digital skills of the labor force, will win the economic battle in these times of social distancing.

\section{Automation and robotization}

The literature abounds in descriptions of the impact of automation and robotisation in the Industry 4.0 era with focus on both, potential opportunities offered at the macro- / microeconomic level, and also the predictions about the future impact on the environment, socially and economically, especially on the labor market in general and at the level of specific jobs in particular.

The scenarios developed (e.g. WEF, Platform Industry 4.0, Hannover Mess, International Federation of Robotics) on how humanity will be affected globally by the 4th wave of industrialization, whose presence has just begun to be felt, oscillating from the optimistic, with new jobs created, much more flexible and better paid, to most pessimistic, 
with millions of jobs lost and people who will no longer be able to make a daily living, possibly with the introduction of a single income as a saving solution.

An increasingly polarized labor market is emerging between low-skilled / nonqualified workers and high-skilled workers, the first ones mentioned being in imminent danger of losing their jobs.

While some authors (Frey \& Osborne, 2013) anticipate a future in which a substantial number of occupations are at risk of computerization and will be fully technologized, others (Arntz et al., 2016), consider this as an overestimation and a wrong approach, saying that the risk of becoming technologized has a high impact only for some tasks related to an occupation, the rest of the tasks being still performed by people. Based on a task-centered approach, Arntz et al. estimate (for 21 OECD countries) an average of only $9 \%$ of automatable jobs, the percentage being in fact heterogeneous among the countries evaluated (e.g., $6 \%$ Korea and $12 \%$ Austria), the differences being due to education, the way work is organized and / or the level of technology of the analyzed countries.

In Romania, the SME Robotization Barometer (Romania Journal, 2020) carried on in March 2020 for Universal Robots shows that about 28\% of SMEs are planning to robotize their production in the next 3 years. Of these, $38.8 \%$ plan to implement collaborative robots and $58.6 \%$ industrial robots. Respondents indicated that they are planning to robotize mainly assembly processes (57\%), pick and place (55.9\%), packaging and palletizing (47.7\%), loading/unloading (46.5\%).

The introducing of robots is considered by $100 \%$ of respondents as a way to increase quality of product, competitiveness and production volume $(97.8 \%)$, reduce the lead time $(92.7 \%)$, to lower production costs and therefore improve its efficiency (92.2\%), eliminate human errors $(91.4 \%)$, obtain the standardization of processes $(90.5 \%)$, as well as increase production flexibility $(88.8 \%)$ and work safety $(88.5 \%)$.

On the other side, according to a survey employed by BestJobs in 2019 (Business Magazin, 2019), more than half of employees interviewed consider that their jobs are threatened by the emergence of robotization and automation. Thus, about $12 \%$ of employees consider that the robots and automation will replace them in the next five years, $14.6 \%$ consider that this is a possibility in the next 5 to 10 years, $11.3 \%$ think their roles could be automated in 10-15 years, and 14\% consider that it would take at least another 20 years for that to happen. However, $48 \%$ do not think that automation could ever fully take over their jobs.

The increasing role of robots push about half of the respondents to constantly develop multiple skills to be able to change their job if necessary. Another $41 \%$ states that they are in a continuum process of learning and training to increase their skills level and mitigate the risk of being replaced by robots. At the same time, only $17 \%$ of respondents do not do anything to develop their skills level.

The survey covered only employees from urban area who use internet regularly. Therefore, it should be considered that Romania is being placed on the 26th position out of 28 European Union Member States within the Digital Economy and Society Index (DESI) for 2020 (European Commission, DESI 2020) and only 75\% of the households with fixed internet connections are in urban areas while, in rural areas, are only $49 \%$.

In many studies, the Central and Eastern European countries are classified among those economies where jobs are at highest risk of being automated (Cséfalvay, 2020). Automotive industry is the best example in this way. Though, the difference is still wide (only 42 robots per 10,000 employees in Romania compared to 1,046 in Belgium), the pace of robotization of this sector put at risk an important number of employees in Romania. 


\section{Autonomous and intelligent vehicles}

The automotive industry accounts for $14 \%$ of Romanian GDP and represents about $26 \%$ of total exports. It is the biggest industry from Romania and the main driver of the economy. Specialists warns that this industry is threatened by the lack of labor force and an educational system capable to tackle with Industry 4.0 challenges (Forbes, 2018).

Emergence of autonomous intelligent vehicles will require more and more specialists with specific skills to sustain further development of this industry and adjacent industries and infrastructure necessaries for functioning of these vehicles.

Despite the importance of automotive industry in Romanian economy, the country is deficient in specialists in this field. Romania is ranked 17th in Europe in number of IT graduates, only 16/1000 inhabitants. Some data (HotNews.ro, 2020) show that there is a deficit between 15,000 and 30,000 IT specialists in Romania. This crisis is amplified by the Brain Drain migration (Panzaru and Reisz, 2017), about 43,000 IT specialists emigrated by now, according to Romanian Government.

Moreover, at the moment there are only a few higher education programs which provide targeted skills needed for the sector of autonomous and intelligent vehicles.

The autonomous vehicles will also lead to disappearing of other jobs such as: truck drivers, couriers, and taxi drivers. For instance, in 2017 there were 150,000 truck drivers in Romania, the most numerous professional category, they being at risk due to emergence of the autonomous vehicles.

\section{Digital nomadism}

Digital nomads are people who use digital technologies to earn a living. They often work remotely from foreign countries, using as a workspace coffee shops, public libraries, coworking spaces, or even recreational vehicles. The phenomenon of digital nomadism is generated by the wish of travel combined with a wish for a better life.

Digital nomads create a work style which is totally different by the conventional types of work. They work in a digital environment, via Internet. Usually, they have individual arrangements within specific projects or manage their own business. Digital nomadism can be considered a form of (solo-)entrepreneurship or "electronic" freelancing (Aguinis \& Lawal, 2013; Laubacher \& Malone, 1998). Freelance digital workers are able to source such work through online marketplaces.

At the moment, destinations such as Cyprus, Thailand, Bali (Wang et al., 2018) or even UK (The Telegraph, 2015) are very popular. Recently, in Romania, particularly cities of Timisoara, Cluj-Napoca and Bucharest became also very popular among digital nomads. The main reasons for choosing Romania as a destination are, on one hand, the costs of living (Romania is cheaper than many European destinations) and, on another hand, the IT infrastructure (e.g., Romania has some of the fastest internet speeds in the world). Therefore, in the cities mentioned before already rise several coworking spaces. For example, in Bucharest for only 5 euro by day it can be rented a place to connect and work.

The presence of digital nomads affects the local labor markets in many directions: new form of competition on labor market (including competition with local graduates), tax and labor obligations, housing market, working hours, type of contracts requested (e.g., increase the request of short-term contracts) etc.

\section{Business models and innovation}

The emergence of digitalization changes the business model of companies in Romania. A research (Valoria Business Solutions, 2017) assessing the perception of CEOs 
about the impact of digitalization reveals the importance of this. For instance, about $35 \%$ of companies states that digitalization has already had a big influence on their business. However, only $31 \%$ consider that they have the appropriate knowledge to cope with this process. At the same time, $61 \%$ of companies say they have difficulties related to digital transformation. Of these, $39 \%$ have doubts they will be able to capitalize on this trend but only $2 \%$ say that they do not consider that digitization is good for the company.

The same research found that companies from the IT sector and mass-media are the most heavily influenced by the digitalization, with about $80 \%$ of respondents agreeing with this. They are followed by $75 \%$ of those in financial-banking services. The industries less or not at all influenced by digitalization in Romania are construction, real estate, food, agriculture, and transport. Surprisingly, the most companies from the utility and energy sector are confident in digitalization but they consider they do not have appropriate knowledge to capitalize on this trend. On the other hand, most of the companies from the transportation sector are also confident in digitalization and consider they know how to capitalize on it.

The importance of digitalization is also highlighted by the existence of a top management leader responsible by this process in most of the companies. For instance, $83 \%$ of companies in the sector of research and development have a designated manager responsible to digital development, $50 \%$ in the utility/energy sector, pharmaceutical and health sector, and $44 \%$ in the trade sector.

On the other hand, $83 \%$ of the companies from construction and real estate sector, $72 \%$ of the companies from industry and production, and $57 \%$ of the companies from services sector (except financial sector) do not have a designated manager to deal with digitalization process.

However, all companies state that expertise required for digitalization of business is important and even they still do not have it, they intend to invest in this direction.

The report also shows that the high-income companies are more oriented in implementing digital solutions than small companies in order to consolidate their dominant position in the market. Small businesses are privileged because they either have a combination of organizational, human, and technological factors that make them to already be a digital company or have very little change to be done in their business model for digitalization.

\section{Civic engagement}

Digital innovation changes the existing and enables new forms of civic engagement, sometimes making the democracy more participative than ever. In Romania, statistics (National Institute of Statistics, 2019) show that young people are the most active category in terms of political and civic participation on the internet. About $14 \%$ of pupils and students have used the internet to express their civic or political view or to involve in different civic initiatives. They were followed by employees with about $13.7 \%$, unemployed persons (12.7\%) and pensioners (only 5.4\%). In addition, it should be noticed the high participation of youngers in elections, mobilization being mainly made through internet. Also, in some cases, demonstrations and street protests broke out due to digital mobilization of people, particularly youngers, through social media platforms.

It is not surprising that young people are very active on the internet, taking into account the trend of migration from real to digital. Not only demographic patterns, but also urbanization and technological advances are driving key changes in how citizens interact, mobilize, and engage with decision-makers. For instance, about $75 \%$ of the households with fixed internet connections in Romania are in urban areas and only $49 \%$ in rural areas. About $74 \%$ of users are active on social media. At the same time, $63 \%$ uses Internet to read news. 
However, the offline engagement is still dominant in Romania, but with the increasing access to the internet and growing up of the digital natives it is expected that social media and online digital platforms will become the new public spaces for civic engagement.

\section{Conclusions and recommendations}

In order to adapt to the digital age, it is necessary to rethink the educational policies, investments in human capital being probably more important today than ever. In many cases, universities today prepare students for jobs in the past and at most in the present and less for the future.

Young people who are on the school benches today, those who guide them as well as those who make up their school curricula have very few ideas about what the labor market will look like and what kind of skills / competencies will be required at the time of graduation. In an interconnected world, with access to information 24/7, where learning new things or enrolling in various online courses / universities is just a click away (e.g., MOOCs Massive Open Online Courses: Khan Academy, Stanfordonline etc), digital technologies are already making their presence felt in the educational environment, giving rise to new learning concepts, for example Higher Education 4.0 (Jeschke \& Heinze, 2014).

At the same time, a priority is to find solutions for persons who already have a job, but rather face or will face problems with the changes brought by digitalization, automation, robotics. The development of lifelong learning in the first place, as well as adaptability, flexibility, critical thinking, creativity, seem to be part of the solutions of the future. Employers will also play an important role in supporting / preparing employees to be able to adapt to the new requirements and changes that will occur in the workplace, as they must rethink their human resource management strategy in order to remain competitive and have the opportunity to a sustainable development in the context of digitalization.

The experts interviewed outlined the following recommendations for action:

- Designing an online national education system (national platforms easy to use and safe, integrated with data administration systems and with those for students' assessment);

- Institutional development projects through digitalization;

- Training programs dedicated for educators/teachers to use the online teaching applications/tools;

- $\quad$ Support for deploying adequate pedagogical resources for online teaching;

- $\quad$ Courses particularly designed for teachers to use advanced technologies;

- $\quad$ Financial support for vulnerable students (in order to acquire laptop, apps etc.);

- Unitary/standardized platforms for online education;

- Adjusting the curricula at all education levels (primary, lower-secondary, uppersecondary) to the specific of digital technologies;

- $\quad$ Setting specific quality targets and requirements for digital (online) activities;

- Creating and financially supporting a "digitalization" program of higher education institutions (Digital University), through which there can be allocated resources necessary to implement integrated informatics systems;

- Major investment in servers and upgraded internal networks, as well as in advanced training for specialized employees;

- $\quad$ Changing the legislation for online education.

One of the main focus should be on updating the curricula to train students so that they have compatible digital skills with those required by the labor market. In order for education and training to respond and, even more, to anticipate the requirements (skills of the future) that have emerged as a result of the implementation of new technologies related to 
digitalization from the labor market perspectives, it is necessary to develop new models to estimate the impact of these technologies on jobs for all sectors of country economy.

Taking into account the challenges that digital technologies can bring to the labor market, McKinsey Global Institute draws a series of possible solutions with positive impact (Manyika, 2017) to overcome them:

- Development of education systems and learning for a changed/different job;

- $\quad$ Determining how the private sector can conduct training;

- Creating incentives for private sector investment to treat human capital like any other capital;

- $\quad$ Exploring partnerships between public and private sectors to stimulate investment in infrastructure facilitation;

- $\quad$ Rethinking income (for example, basic universal income);

- $\quad$ Rethinking support for transition and safety of affected workers;

- $\quad$ Adopt solutions compatible with technologies that can be used in the labor market to improve correlation, access and reduce skills gaps;

- $\quad$ Focus on job creation;

- $\quad$ Innovating the way people work with cars;

- Control the benefits of technological productivity to create growth, surpluses and labor demand, which configure space for creative solutions and ultimately benefit from it all.

The wave of digitalization is so strong that change is inevitable, including in education. Thus, Education 4.0 appeared as a conceptual response, an ubiquitous concept in current educational systems, in which people and technology are brought together to create new learning opportunities (Hussin, 2018).

A framework and tool also built to support educators at all levels of education at European level is Digital Competence of Educators (Redeckers, 2017). The European Framework for the Digital Competence of Educators (DigCompEdu) represents a fundamental approach that acknowledges the keen need of educators in many European countries for profession-specific set of digital skills, in order to take advantage of the potential of digital technologies to improve and innovate education.

\section{REFERENCES}

AgoraDigi (2020). Romania needs a concrete strategy and measures for digital education. URL: www.digi24.ro/opinii/romania-are-nevoie-de-o-strategie-si-masuri-concrete-pentru-educatia-digitala1305107.

Aguinis, H., \& Lawal, S. O. (2013). eLancing: A review and research agenda for bridging the science-practice gap. Human Resource Management Review, 23(1), 6-17.

Arntz, M., T. Gregory and U. Zierahn (2016). The Risk of Automation for Jobs in OECD Countries: A Comparative Analysis, OECD Social, Employment and Migration Working Papers, No. 189, OECD Publishing, Paris, DOI: 10.1787/5jlz9h56dvq7-en.

Business Magazin (2019). Best jobs Survey. URL: www.businessmagazin.ro/actualitate/sondaj-bestjobs-cejoburi-cred-romanii-ca-nu-pot-fi-inlocuite-niciodata-de-roboti-preotii-in-topul-clasamentului-18166957.

Coibion, O., Gorodnichenko, Y., \& Weber, M. (2020). Labor markets during the covid-19 crisis: A preliminary view. National Bureau of Economic Research, no. w27017.

Cséfalvay Zoltán (2020). Robotization in Central and Eastern Europe: catching up or dependence?, European Planning Studies, 28:8, 1534-1553, DOI: 10.1080/09654313.2019.1694647.

Dingel, J. I., \& Neiman, B. (2020). How many jobs can be done at home? National Bureau of Economic Research, no. w26948.

European Commission (2020). Digital Economy and Society Index. URL: https://digitalstrategy.ec.europa.eu/en/library/digital-economy-and-society-index-desi-2020

European Commission/EACEA/Eurydice (2019). Digital Education at School in Europe. Eurydice Report. Luxembourg: Publications Office of the European Union. URL: www.eacea.ec.europa.eu/national- 
policies/eurydice/sites/eurydice/files/en_digital_education_n.pdf.

Forbes (2018). The car industry is accelerating the future. URL: www.forbes.ro/articles/18-pentru-2018industria-auto-accelereaza-viitorul-105594.

Frey, C. B. \& Osborne, M. (2013). The Future of Employment: How Susceptible Are Jobs to Computerisation? Oxford: Oxford Martin School, Programme on the Impacts of Future Technology and Programme on Technology and Employment, Oxford University. URL: www.oxfordmartin.ox.ac.uk/downloads/academic/The_Future_of_Employment.pdf.

HotNews.ro (2020). Press-Release. URL: www.economie.hotnews.ro/stiri-telecom-24368223-hemoragiecreiere-IT-covid-19-romania-absolventi-deficit-directorat-national-de-securitate-cibernetica-cert-ro.htm.

Hussin, A. A. (2018). Education 4.0 made simple: Ideas for teaching. International Journal of Education and Literacy Studies, 6(3), 92-98.

Jeschke, Sabina \& Heinze, Ute. (2014). Higher Education 4.0 - Trends and Future Perspectives for Teaching and Learning. DOI: 10.13140/RG.2.1.1509.0002.

Laubacher, R. J., \& Malone, T. W. (1998). The Dawn of the E-lance Economy. Harvard Business Review, 76(5).

Manyika, J. (2017). A future that works: AI, automation, employment, and productivity. McKinsey Global Institute Research, Tech. Rep, 60.

Mas, A., \& Pallais, A. (2020). Alternative work arrangements (No. w26605). National Bureau of Economic Research.

Mongey, S., \& Weinberg, A. (2020). Characteristics of workers in low work-from-home and high personalproximity occupations. Becker Friedman Institute for Economic White Paper.

National Institute of Statistics (2019). Population Acces to IT\&C. URL: www. insse.ro/cms/sites/default/files/field/publicatii/accesul_populatiei_la_tehnologia_informatiei_si_comuni catiilor_romania_2019.pdf.

Panzaru, C., \& Reisz, R. D. (2017). Brain Drain Migration from Romanian Academia. The End of a Mirage. European Review of Applied Sociology, 10(14), 34-48.

PwC Report (2019). The skills shortage generates total losses of over EUR 7 billion to Romanian private businesse. URL: www.pwc.ro/en/press-room/press-releases-2019/pwc-report--the-skills-shortagegenerates-total-losses-of-over-e.html.

Redecker, C. (2017). European Framework for the Digital Competence of Educators: DigCompEdu. Punie, Y. (ed). Publications Office of the European Union, Luxembourg, doi:10.2760/159770.

Romania Journal (2020). SME Robotization Barometer Research: Romanian Entrepreneurs Plan to Invest In Robotization. URL: www.romaniajournal.ro/business/sme-robotization-barometer-research-romanianentrepreneurs-plan-to-invest-in-robotization/.

The Telegraph (2015). Living and working in paradise: the rise of the 'digital nomad'. URL: www.telegraph.co.uk/news/features/11597145/Living-and-working-in-paradise-the-rise-of-the-digitalnomad.html.

Valoria Business Solutions (2017). Digitisation barometer in Romanian companies. URL: www.valoria.ro/portfolio/barometrul-digitalizarii-in-companiile-din-romania/.

Wang, B., Schlagwein, D., Cecez-Kecmanovic, D., \& Cahalane, M. C. (2018). Digital work and high-tech wanderers: Three theoretical framings and a research agenda for digital nomadism.

World Economic Forum (2018). Understanding the impact of digitalization on society. Report. URL: www.reports.weforum.org/digital-transformation/understanding-the-impact-of-digitalization-onsociety/ 